\title{
Winning Competition through the Management of Word of Mouth Viral Marketing, and Brand Equtiy on Private Universities
}

\author{
Herry Agung Prabowo \\ Farida \\ Lecturers in the Department of Industrial Engineering, Mercu Buana University, Jakart \\ E-mail: herryagung@gmail.com, faridaghozali@gmail.com
}

\section{Doi:10.5901/mjss.2015.v6n5s5p118}

\begin{abstract}
There are approximately 3.300 universities in Indonesia, which consists of 3.200 private universities and 100 public universities. The growth of private universities was 8 percent annually, or an average of 200 universities per year. The rapid development of private universities results in increasingly competitive competition in acquiring new students. In higher education industries, winning the competition means that the high school graduates choose selected universities to continue their studies. Brand equity is one of the important concept in brand management because strong brand equity will make their brand chosen by its prospective customers. In contrast to general companies which use marketing mix variables as a source of brand equity, universities have a wide variety of targets. So the role of personal communication is very important to validate a university brand. Other forms of personal communications are words of mouth communications (WOM) and communication through the internet media (viral marketing). This research aims to understand the effects of WOM, viral marketing, and brand equity of private universities on decision to choose private universities. Data in the forms of brand equity variables, WOM variables, viral marketing variables, and decision to choose variables are obtained from the questionnaires. The number of samples taken is as many as 750 from high school students in Jakarta and Tangerang. The selected private universities are Mercu Buana University, Trisakti, Bina Nusantara, Gunadarma, Budi Luhur, and Esa Unggul. The data are statistically processed by the method of structural equation modeling (SEM) using SPSS and AMOS. The results of this research indicate that the decision to choose is influenced by brand equity and WOM, while the brand equity is significantly influenced by WOM communications and viral marketing. Viral marketing do not significantly influence the decision to choose, it influence to decision to choose through brand equity. So, private universities should be able to build strong brand equity through positive WOM and viral marketing. The success of managing both WOM and viral marketing can be used as an advantage to win the competition among private universities.
\end{abstract}

Keywords: brand equity, word of mouth (WOM), viral marketing, and private universities

\section{Introduction}

There are approximately 3.300 universities in Indonesia, which consists of 3.200 private universities and 100 public universities. The growth of private universities was 8 percent annually, or an average of 200 universities per year. (Suharyadi, Kompas 2010). The rapid development of universities results in increasingly competitive competition in high education industries to obtain new students in universities, especially the private ones. If they failed to fulfill the economic scale of student number, they will lack of money to run the university and finally die/closed. In these industries, winning the competition means that the prospective university students choose the universities to continue their studies. The concept of branding is an important part of selling private universities to attract, retain and build loyalty to prospective students as well as the existing students. Strong brand equity will make a brand be chosen by prospective customers.

In contrast to most sources of company brand equity, university brands have broad target audience. Some parties who must be taken into considerations are the potential candidates (in this case, the high school students), family and their high school teachers (often also called as a source of recommendation or influencers in choosing the universities), and the alumni. So the role of personal communications is very important to validate the university brand. One form of personal communications is word of mouth (WOM). Another similar personal communications to WOM but using the internet media is viral marketing. Viral marketing is expected to result in the dissemination of information rapidly and massively.

The strength of WOM is realized as a result of the ineffectiveness of the mass media as promotional tools because consumers can only remember five to seven advertisements per day (Schiffman and Kanuk, 2000). The results of a 
survey conducted by one of the private universities in Jakarta (Mercu Buana University (UMB)) show that more than 40\% of prospective students obtain information about UMB through WOM. In the last 3 years UMB has also conducted personal communications, viral marketing through the internet and the result of students obtaining information through this media is only $10 \%$. Through research focusing on the university industry, the principal objective of this paper are to learn how WOM and viral marketing influence both the brand equity and the decision of choosing private university, and how the brand equity influences the decision of choosing private universities.

\section{Literature Review}

\subsection{Buying Decision}

According to Peter and James (2004) the buying decision process is when a consumer makes the decision to purchase a variety of products and brands beginning with the needs recognition, information search, information evaluation , and makes purchases and then evaluates the decision after the purchase. Schiffman dan Kanuk (2010) stated that buying decision process is influence by many external factors such as marketing activities, family, culture, sub culture etc. Price, reference group, marketing communication, and brand are significantly influence the decision of choosing private university (Sawaji, Jamaluddin, Hamzah Djabir, and Taba, Idrus. 2009). According to Engel, Blackwell, and Miniard (2006), there are five level stages of the consumers' buying decision models: problem recognition, information search, alternative evaluation, purchase decision and post purchase behavior. Considering those models, this research is conducted on prospective consumers, high school students, who use the services of private universities, for those reasons, the discussion of buying decisions is conducted only to the fourth stage, namely the decision to buy.

\subsection{Brand equity}

Kotler and Keller (2007) define brand equity as the added value given to products and services. Brand equity is very important for marketers because the brand equity can increase consumer preference towards a brand. Products with strong brand equity can give a strong foundation of brand and are able to develop the existence of brand in any competition in the long term. Brand equity factors influencing customer purchase decision criterion (Nigam, Ashutosh, Kaushik, Rajiv, 2011). The role of the brand in universities is considered very important. In terms of education, the service is more than just a simple set but it is the real feature which is a complex bundle of benefits which meet the needs of customers (Ivy, 2008). Brand image and reputation help raise the level of brand equity on prospective students (Nguyen \& LeBlanc, 2001). Managing the sources of brand equity will make marketers succeed in developing high brand equity and generating financial returns. According to Noorjaya, M. Yasin, Mohammad Noor and Osman Mohamad Naseer (2007), sources of brand equity include family influences, viral marketing, and integrated Marketing Communication (IMC). Aaker (1991) builds brand equity model in five dimensions. For the purposes of this research, only four dimensions will be reviewed. These four dimensions of brand equity are: brand awareness, brand loyalty, perceived quality of the brand, and brand association.

\subsection{WOM}

According Word of mouth Marketing Association, the definition of the word of mouth is the efforts to pass the information from one consumer to another consumer (www.womma.com, 2007). In the community, WOM is also known as person to person communications. According to Hendriani (2008) $78 \%$ of consumers in Indonesia trust what is told by friends on pricing and products offered by the store rather than by trusting promotion or discount prices that shops give, even than doing research / comparing prices at the stores by reading leaflets and flyers. WOM is more credible than a sales person, and can reach consumers more quickly than on advertising and direct-mail, because WOM strength lies in its ability to provide recommendation (referral). If the experience is positive, the recommendation could be an effective promotional tool (Basalamah, Muhammad Fauzan. 2010).

\subsection{Viral Marketing}

According to Brown and Reingen in Noorjaya, M. Yasin, Mohammad Noor and Osman Mohamad Naseer (2007), viral marketing is also different from the traditional general WOM marketing. Traditionally, WOM has been conceptualized and explored as an interpersonal exchange of information between individuals / relatives. Usually, it is assumed that the 
receiver of the message has confidence in the value of the information given by the provider, because they have perceived similarity (Gilly et al 1998). From the perspective of an online context, there is usually no familiarity between the sender and the receiver of the message in the electronic word of mouth (e-WOM). According to Lerrthaitrakul, W and Panjakajorsak, V. (2014) e-WOM channels directly influence consumer's buying decision-making process in the low cost carriers.

\subsection{Conceptual Framework}

Based on a review of the theories of brand equity, word of mouth, viral marketing, buying decisions, as well as previous researches, then it is planned the conceptual framework of the research, as in Figure 1.

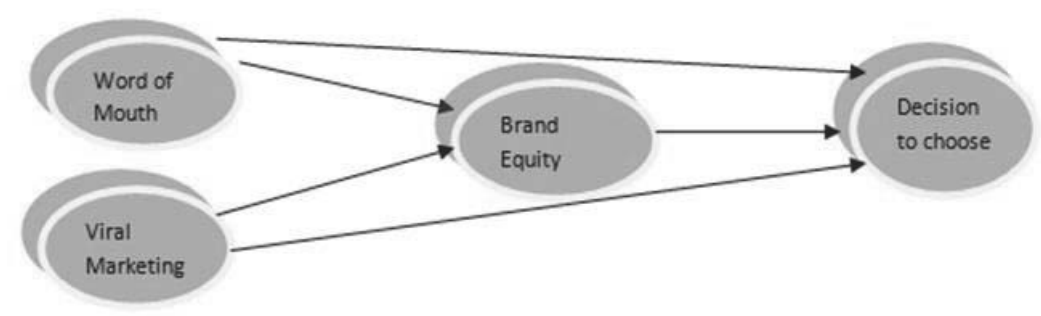

Figure 1. Conceptual Framework

\section{Method}

The focus of this research is the high school students in Jakarta and Tangerang. Jakarta and Tangerang were chooses because both cities have a big number of private universities and high school students in Indonesia. The samples of high school are determined by purposive, while sampling for each high school is done randomly. The selected students are given questionnaires to fill out to share their perceptions of WOM, viral marketing, and brand equity in private universities. The selected private universities are UMB, Trisakti, Binus, Gunadarma, Budi Luhur, and Esa Unggul. The number of selected respondents is 750 students, which is well above the critical sample size of 200 for developing structural equation models (Hair et al., 1998).

Variables observed in this research are the dimensions of WOM, viral marketing, brand equity, as well as the dimension of the decision to choose. Measurement of the observed variables uses a five-point Likert scale with scale anchors from "1" strongly disagree to "5" strongly agree. Dimensions of brand equity consist of four dimensions as suggested by Aaker (1991), namely, brand awareness, brand association, perceived quality and brand loyalty. Dimensions of WOM and viral marketing as suggested by Brown (2005) namely the intensity information talked, positive information, the convincing information, and the information to recommend the private universities. While for the decision to choose, it will be used five indicators of the level of consumers' buying decision process from Philip Kotler dan Gary Amstrong (2006) namely needs recognition, information search, alternative evaluation, and decision to choose.

Statistical techniques in this research use the model of SEM (Structural Equation Model) of the package AMOS (Analysis of Moment Structure). The advantage of SEM is its ability to assess and fix measurement error that can not be done by other procedures. Another advantage is the possibility analyzed a model with observed variables and latent variables as well as the ease in helping researchers performed a multivariate analysis simultaneous tiered basis (Ferdinand, 2006) .

\section{Result And Discussion}

The aims of this research are to find out the things which influence students in choosing private universities. From the results of this research, it is described three things that are expected to affect the decision of selecting the private universities, while the preliminary results; it is described things that affect the decision in choosing the private universities, such as WOM, viral marketing, and brand equity. Furthermore, it will be discussed the things which significantly influence the decision of choosing private universities on prospective students. 
Table 1. Descriptive Statistics of Respondents Answer about WOM and Viral Marketing

\begin{tabular}{|c|c|c|c|c|}
\hline \multicolumn{2}{|c|}{ Variable/Indikator } & $\mathbf{N}$ & Mean & Mode \\
\hline \multicolumn{5}{|c|}{ Word of Mouth } \\
\hline 1. & WOM 1 (Intensity talks about private universities) & 723 & 3,56 & 4,00 \\
\hline 2. & WOM 2 (Positive talks about private universities) & 723 & 3,42 & 3,00 \\
\hline 3. & WOM 3 (Talks about private universities as a quality campus) & 723 & 3,35 & 3,00 \\
\hline 4. & WOM 4 (Talks about recommending to study at private universities) & 723 & 3,12 & 3,00 \\
\hline \multicolumn{5}{|c|}{ Viral Marketing } \\
\hline 1. & Viral 1 (Intensity talks about private universities) & 723 & 3,01 & 3,00 \\
\hline 2. & Viral 2 (Positive talks about private universities) & 723 & 3,21 & 3,00 \\
\hline 3. & Viral 3 (Talks about private universities as a quality campus) & 723 & 3,24 & 3,00 \\
\hline 4. & Viral 4 (Talks about recommending to study at private universities) & 723 & 3,13 & 3,00 \\
\hline \multicolumn{5}{|c|}{ Brand Equity } \\
\hline 1. & Brand awareness & 723 & 3,24 & 3,00 \\
\hline 2. & Brand association & 723 & 3,38 & 3,00 \\
\hline 3. & Perceived quality & 723 & 3,41 & 3,00 \\
\hline 4. & Brand loyalty & 723 & 2,93 & 3,00 \\
\hline \multicolumn{5}{|c|}{ Decision to buy } \\
\hline 1. & Needs recognition & 723 & 3,87 & 5,00 \\
\hline 2. & Information Search & 723 & 3,71 & 4,00 \\
\hline 3. & Alternative Evaluation & 723 & 3,33 & 3,00 \\
\hline 4. & Decision to choose & 723 & 2,94 & 3,00 \\
\hline
\end{tabular}

Described from the students' responses to the questions about WOM and viral marketing, it shows that the respondents have not agreed with the proposed statements but they do not reject them either. The average value of WOM is still higher than the average value of viral marketing. WOM1 indicator has a mode score of 4.00; it indicates that the majority of respondents have agreed that private universities is often talked about.Table 1 is a table of descriptive statistics of respondents about WOM, Viral Marketing, brand equity, and decision to choose.

The average score of brand equity of private universities have not reached 4 , meaning they do not agreed with $\mathrm{t}$ he proposed statements but they do not reject them either. The stage of needs recognition has the mode score of 5.00, meaning that the respondents strongly agree that they need to continue their studies to universities. The stage of information search has a mode score of 4.00 , meaning that most of the respondents agree that they have started searching for information on state and private universities from various sources. While the step of determining the selection of alternatives and choosing the existing alternatives is still neutral. This means that most of them have not determined and selected the specific private university yet as an option to continue their studies, and they have not agreed that they will choose one private university as the University of their Choice.

Table 2. Confirmatory Analysis

\begin{tabular}{|c|c|c|c|}
\hline Variable/Indikator & Loading Factor & Extract Variant & $\begin{array}{l}\text { Construct } \\
\text { Reliability }\end{array}$ \\
\hline \multicolumn{4}{|l|}{ Word of Mouth } \\
\hline 1. WOM 1 (Intensity talks about private universities) & .755 & & \multirow{4}{*}{0.8250} \\
\hline 2. WOM 2 (Positive talks about private universities) & .800 & & \\
\hline 3. WOM 3 (Talks about private universities as a quality campus) & .728 & & \\
\hline 4. WOM 4 (Talks about recommending to study at private universities) & .655 & & \\
\hline \multicolumn{4}{|l|}{ Viral Marketing } \\
\hline 1. Viral 1 (Intensity talks about private universities) & .765 & & \multirow{4}{*}{0.8577} \\
\hline 2. Viral 2 (Positive talks about private universities) & .778 & & \\
\hline 3. Viral 3 (Talks about private universities as a quality campus) & .845 & & \\
\hline 4. Viral 4 (Talks about recommending to study at private universities) & .710 & & \\
\hline \multicolumn{4}{|l|}{ Brand Equity } \\
\hline 1. Brand awareness & .781 & & \multirow{4}{*}{0.8446} \\
\hline 2. Brand association & .766 & & \\
\hline 3. Perceived quality & .800 & & \\
\hline 4. Brand loyalty & .686 & & \\
\hline \multicolumn{4}{|l|}{ Decision to buy } \\
\hline 1. Needs recognition & .396 & & \multirow{4}{*}{0.7389} \\
\hline 2. Information Search & .715 & & \\
\hline 3. Alternative Evaluation & .690 & & \\
\hline 4. Decision to choose & .786 & & \\
\hline
\end{tabular}

Source: Data processed Research 2014 


\subsection{Confirmatory Factor Analysis}

The results of confirmatory factor analysis show that all indicators of the research variables have a value of greater than 0.5 , so it is valid to measure the research variables. For the measurement tools based on the value of variant extract, all have a value of greater than 0.5 , while the value of construct reliability is above 0.7 . This means that the measuring instruments qualify the reliability study. Table 2 shows the results of confirmatory factor analysis. Dimensions that have the highest loading factor value is the most important dimension of each variable. So the most important dimensions are positive talks about private universities for WOM, talk about private universities as a quality campus for Viral Marketing variable, perceived quality for Brand Equity variabel, and decision to buy for Decission to Choose variable.

\subsection{Goodness of Fit Model Test}

RMSEA value of 0.035 indicates that the model is good and it can be used for analysis. The value of CMIN/DF in this research is 1,886 , value of $\mathrm{CFI}$ is 0.986 , and TLI 0,982 . Various considerations above indicate that the model is acceptable for further analysis.

\subsection{Structural Equation Analysis}

The effects of WOM and viral marketing on brand equity, and the effects brand equity on choosing decisions are presented in Table 3 and figure 2. Criteria used for testing are based on the criterion P value, cut-off value of CR with a significance of 0.05 .

Table 3. Test Result

\begin{tabular}{|l|c|l|c|c|c|c|l|}
\hline \multicolumn{2}{|c}{} & Std. Estimate & Estimate & C.R. & P & Remarks \\
\hline Brand Equity & $\leftarrow$ & WOM & .414 & .041 & 9.977 & $\star \star \star$ & Significant \\
\hline Brand Equity & $\leftarrow$ & Viral Marketing & .286 & .036 & 7.939 & $\star \star \star$ & Significant \\
\hline Buying decision & $\leftarrow$ & Brand quity & .357 & .071 & 5.016 & $\star \star \star$ & Significant \\
\hline Buying decision & $\leftarrow$ & WOM & .085 & .037 & 2.270 & .023 & Significant \\
\hline Buying decision & $\leftarrow$ & Viral Marketing & .019 & .027 & .707 & .480 & Not Significant \\
\hline
\end{tabular}

Source: Data processed Research 2014

The table shows that the variable that significantly affects the decision of prospective students to choose private universities are WOM and brand equity, whereas viral marketing does not significantly affect directly on the decision to choose. Viral marketing variables significantly influence the brand equity.

The direct influence of WOM on brand equity is significant, this result are consistent with the research of Hendriani (2008) which states that $78 \%$ of consumers in Indonesia trust what is told by friends on pricing and products offered by the store rather than by trusting promotion or discount prices that shops give, even than doing research / comparing prices at the stores by reading leaflets and flyers. Brand equity is significantly influenced by viral marketing, support the previous research conducted by Noorjaya, M. Yasin, Mohamad Naseer Noor and Osman Mohamad (2007) that viral marketing effect on strengthening brand equity significantly for mobile products, and personal computers. Decision to choose is significantly influenced by WOM is consistent with the research of Sawaji, Jamaluddin, Hamzah Djabir, and Taba, Idrus (2009) that of reference group is significantly influence the decision of choosing private university. And decision to choose isn't significantly influenced by viral marketing is support the previous research conducted by Tommi Wijaya and Eristia Lidia Paramita (2014) that e-wom didn't effect purchase decision significantly to DSLR cameras. 


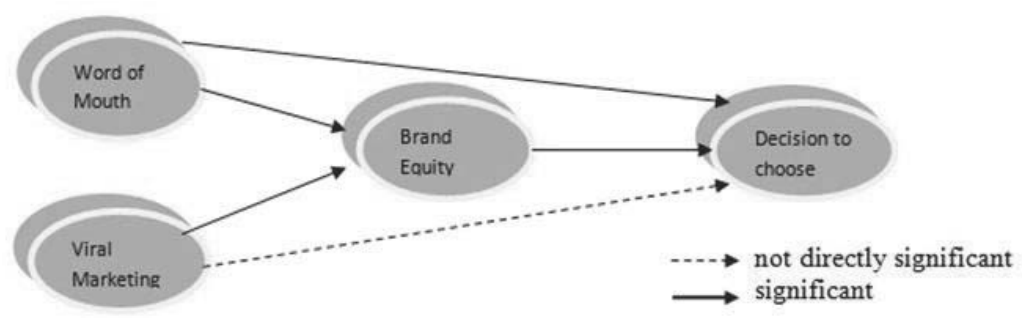

Figure 2. Test Result

\section{Managerial Implication}

The above facts indicate that prospective students will consider the brand equity of a private universities to be selected as a college to continue their studies. Not surprisingly, high school graduates especially in Indonesia, compete to enter state universities as their primary goals to continue their studies. Because state universities represent high quality universities and have a very strict selection process. So it is an honor for them to be accepted in state universities.

Private universities in Indonesia is considered to be choose if they were not accepted to study at state universities. On the other hand the number of private universities in Indonesia is far greater than the number of state universities. In order to be selected, private universities should be able to build its brand equity as a quality campus (perceived quality) through positive talk (WOM 2) according to perceived quality variable. Perceived quality and WOM2 are the most important dimension of brand equity and WOM. Private universities as a quality campus will be able to build positive brand equity, which can give pride to the prospective students. In addition, private universities should be able to increase the satisfaction of their student so that they can create a positive conversation ( WOM2). Satisfied students will be able to recommend private universities to be selected. In order to known as quality campus, private universities should continuously and intensively create talks (as a quality campus) through e-WOM (viral 3 ) due to viral 3 is the most important dimension of viral marketing. The more positive talk about private universities, the more powerful brand equity of private universities.

\section{Conclusion}

In choosing a particular private universities, prospective customers will consider the brand equity of the private universities. Private universities's brand equity is influenced by person to person communications or commonly referred to as WOM and by what people talk about through the internet media (viral marketing). However, viral marketing do not affect directly the decision of selecting the private universities, but it affects the decision to choose through brand equity.

\section{References}

Aaker, D. A. (1991). "Managing Brand Equity". The Free Press, New York.

Brown, Barry, Dacin, and Gunst. (2005), "Spreading the world : investigating antecedents of consumers positive word of mouth intentions and behaviors in a retailing context" Journal the Academy of Marketing Science, Vol 33, N0 : 2.

Chen, C, F. and Tseng, W, S. (2010)." Exploring customer-based airline brand equity: evidence from Taiwan". Transportation Journal, Vol. 49.

Cruz, D. And Fill, C. (2008), "Evaluating viral marketing : Isolating the key criteria" Emerald Insight, Marketing Intelligence and Planning, Vol 26, N0: 7.

Engel J.F., R.D. Blackwell, and P.W. Miniard (1995)." Consumer Behaviour". Eight Edition. Dryden Press.

Ferdinand, Augusty. (2006), "Structural Equation Modelling: in management research". Four Edition. BP UNDIP.

Hair, J.F., Andersen, R.E., Tatham, R.L. and Black, W.C. (1998),Multivariate Data Analysis, 5th

ed., Prentice-Hall, Englewood Cliffs, NJ.

Harrison-Walker, L, J. (2001) "Measurement of WOM communication and an investigation of service quality and customer commitment", Journal of service research, Vol 4, No: 1.

Iranita. (2012)." Analysis Of Factors Affecting The Choice Of Students Faculty Economic Raja Ali Haji Maritime University In Creating Competitive Advantage". JEMI, Vol. 3, No. 2, Desember 2012

Keller, K.L. (2008). "Strategic brand management: building, measuring, and Management brand equity". Prentice Hall, New Jersey.

Kotler, P. and Keller, K, L. (2007)." Marketing management". 12th edition, Pearson education, Inc., Upper saddle river, New Jersey. 
Lerrthaitrakul, W and Panjakajorsak, V. 2014. "The Airline Service Quality Affecting Post PurchaseBehavioral Intention: Empirical Evidence from the Low Cost Airline Industry". International Journal of Trade, Economic, and Finance. Vol 5, No 2 April 2014.

Nguyen, N. Dan Leblanc, G. (2001), "Corporate image \& coporate reputation in customers' retention decision in services", Journal of retailing \& customer services.

Noorjaya, M. Yasin, Mohamad Naseer Noor and Osman Mohamad. (2007) "Does Image of country of origin matter to brand equity", Journal of Marketing Vol 99, No 4.

Sawaji, Jamaluddin, Hamzah Djabir, and Taba, Idrus. 2009. "An Analysis of Student's Decision Making to Choose Private University in SouthSulawesi".www.pasca.unhas.ac.id/jurnal/file.

Schiffman, G. Leon \& Kanuk, Leslie Lazar. (2010) "Consumer Behavior". 10th edition, Prentice Hall.

Kompas, Daily Newspaper. Indonesia. 21st April 2010

Yvi, J. (2008), "A new higher education marketing mix : the 7Ps for MBA marketing" International Journal of Education Management, 22 (4).

Wijaya, T and Paramita E.L.(2014),"The Impact of E-WOM on Customer Buying Decision on DSLR Camera”.National Conferrence and Call for Paper(Sancal 2014)ISBN : 978-602-70429-1-9. 